\title{
Sketch of the History of Architecture in Scotland, Ecclesiastical and Secular, Previous to the Union with England in 1707
}

Joseph Robertson F.S.A., Scot

To cite this article: Joseph Robertson F.S.A., Scot (1856) Sketch of the History of Architecture in Scotland, Ecclesiastical and Secular, Previous to the Union with England in 1707, Archaeological Journal, 13:1, 228-244, DOI: 10.1080/00665983.1856.10851009

To link to this article: $h$ ttp://dx.doi.org/10.1080/00665983.1856.10851009

电 Published online: 10 Jul 2014.

Submit your article to this journal $\pi$ 
SKETCH OF THE HISTORY OF ARCHITECTURE IN SCOTLAND, ECCLESIASTICAL AND SECULAR, PREVIOUS TO THE UNION WITH ENGLAND IN 1707. ${ }^{1}$

BY JOSEPH ROBERTSON, F.S.A., Scot, Superintendent of Searches in the Literary and Antiquarian Department of Her Majesty's General Register House, Edinburgh.

Is compliance with a suggestion that such an outline, however rudely or feebly drawn, might not be wholly unacceptable to the Archaeological Institute, I venture on an attempt to sketch, as briefly as may be, the chief epochs in the annals of Scottish architecture, as well ecclesiastical as civil or secular, previous to our happy union with England, in the beginning of the XVIIIth century. If I am unable to produce pictorial illustrations-for which I must be content to refer to $\mathrm{Mr}$. Billing's admirable volumes ${ }^{2}-\mathrm{I}$ shall not enter upon any consideration of details-which (so far as the first part of my subject is concerned) will be found copiously collected and classified in Mr. Thomas S. Muir's "Descriptive Notices of Scotch Collegiate and Parochial Churches," and "Notes on Remains of Ecclesiastical Architecture in the South of Scotland."

Taking no account of buildings of which no vestiges survive-such as the white-walled church, a marvel to the British tribes, which St. Ninian reared on the shores of Galloway by the hands of builders brought from Gaul, about the beginning of the Vth century ; and "that church of stone after the Roman manner," for the construction of which as Bede tells us, architects were sent to the Pictish King from the venerable historian's own monastery in Northumberland in the first years of the VIIIth century ;-passing over also such objects as those graven crosses and incised pillars of stone which belong rather to the department of sculpture than to the province of architecture; and those

1 Communicated to the Architectural Section, at the Meeting of the Institute in Edinburgh, July, 1856.

2 Baronial and Ecclesiastical Antiqui. ties of Seotland. London, 1845-52. 4 to, 4 vols.

${ }^{3}$ London, $1848.8 \mathrm{vo}$

4 Edinburgh, 1855. 8vo. 
rocky caves for which nature had done so much that scarcely any art was needed to shape them into oratories or penancecells for St. Ninian and St. Columba, St. Kentigern and St. Rule, St. Serf, St. Kieran, St. Maoliosa, St. Gernad, and many others of our early missionaries : dismissing these, I say, the Ecclesiastical Architecture of Scotland may be distinguished into three great periods-one, the earliest, during which the influence of Ireland prevailed; a second, by far the richest, during which we followed the footsteps of England; a third, the last, during which we borrowed largely from France.

The Firsi, or Scoto-Irish period, as it may be called, extends over more than five centuries, from about the middle of the VIth to near the end of the XIth ; from the landing of St. Columbkille on Iona, in the year 565, to the marriage of St. Margaret with King Malcolm at Dunfermline, in the year 1070. Of the few and scanty relics of this period, the best known are the round towers of Brechin and Abernethy. The Irish character of both is sufficiently obvious. Neither would seem to belong to the most ancient order of the class. The religious community which found shelter within the tower of Brechin, does not seem to have been founded until the end of the Xth century ; and there are features in the tower of Abernethy which appear to show that it is the younger of the two. It is amongst the distant Western Isles that we must seek for the oldest, if not the most instructive, edifices of this early age. On Eilean Naomh, an uninhabited rock midway between Scarba and Mull, are remains as well of those circular dome-roofed cells, which in Ireland are known as " bee-hive houses," as of a building, probably a chapel, of which the walls are without cement, and the doors and windows are square-headed. The skilled glance of my friend, the Rev. Dr. Reeves of Ballymena, author of the "Ecclesiastical Antiquities of Down, Connor and Dromore," at once recognised in these ruins the characteristics of the Irish architecture of the VIIth or VIIIth century. The same very learned and accurate antiquary has kindly placed in my hands a proof-sheet of his forthcoming edition of Adamnan's Life of St. Columba, in which he gives an account from his own observation of a "cyclopean cashel," and of a chapel built without mortar, in the Isle of Skye, which may be contemporary, he believes, if not with the great Apostle 
of Scotland, at least with the first or second generation of his disciples. On the island of Inchcolm, in the Firth of Forth, are still to be seen the ruins of an oratory of the same type, if not of the same remote age, as the oratories of St. Senan and Gallerus in Ireland-the capellula in which, in 1123, the shipwrecked king of the Scots found a hermit serving St. Columbkille. When I mention some almost obliterated traces at Iona, some doubtful relics near the ancient sanctuary of St. Blane in Bute, and what would seem to be a "beehive house" in the rarely-visited island of St. Kilda, I believe that I nearly exhaust the meagre catalogue of the ascertained monuments of the Celtic or Scoto-Irish age of our architecture.

The Second, or Anglo-Scottish era, embraces three centuries, reaching from about the end of the XIth to about the end of the XIVth, from the accession of St. Margaret in 1070 to the accession of the Stewarts in 1371. This was emphatically the great age of ecclesiastical architecture in Scotland, the noontide at once of the spiritual glory and earthly grandeur of the Medieval Church in the north. As it was an English Princess, the saintly niece of the meek Confessor, who laid the foundations - who laid the foundations as well of our social and political civilisation-so it was by English hands that the fabric was built up. English monks peopled our monasteries, English priests served our parochial cures, English bishops ruled our episcopal sees. Our cathedrals framed their constitutions after the English models of Salisbury and Lincoln; our provincial councils copied their canons from the English synods of Oxford and Durham; the language and rites of our liturgy were the language and rites of the English use of Sarum. When such was the character of the Scottish Church, it need scarcely be added that her architecture was English too. Throughout the three centuries which I have named, the ecclesiastical edifices of Scotland, except in their humbler dimensions, their smaller number, and their less copious and less costly decoration, differ from those of England only as the churches of one English shire may differ from those of another, or as the constructive art of one French province varies from that of another French province. The Norman, or Romanesque, the First Pointed or Early English, and the Second Pointed or Decorated, are substantially the same on both banks of Tweed; the same 
in their general features, nearly the same in their date and duration.

Of our Romanesque buildings, the earliest is the nave of the conventual church of Dunfermline, begun, it would seem, in the last years of the XIth century, and consecrated in the middle of the XIItl. Its foundations were laid by the same King of Scots who about the same time laid the foundations of Durham ; and looking to the close resemblance between the two, it seems not improbable that they may have been planned by the same head, if not executed by the same hands. Of our other Romanesque structures-such as the noble cathedral of St. Magnus, at Kirkwall (if a work built when the Orkneys were part of Norway, may fairly be claimed as Scottish), the conventual minsters of Kelso and Jedburgh, the parish churches of Dalmeny, Leuchars, and Tyninghame-all are of a comparatively late order, some of them indeed bordering on the Transition to First Pointed. One Romanesque building-the old church of St. Rule, the elder of the two cathedrals at St. Andrews-shows a feature to which, so far as I know, there is no existing parallel in England - a square central tower, more than a hundred feet high, and, so, wholly disproportioned to the diminutive choir from which it springs. There is sufficient evidence that it was built between the years 1127 and 1144, by an Austin Canon from the English monastery of St. Oswald near Pontefract, who then filled the primatial see of the Scots. The object of the builder, as I think I could show from some inedited documents, may have been to surpass the neighbouring and rival church of the Culdees of the Heugh (that is the Rock); and could we be sure that the Culdee canons of St. Andrews had a round tower like their Culdee brethren of Abernethy and Brechin, it would be easy to conjecture why Bishop Robert carried his rectangular tower to such an unusual altitude.

The choir of the later and larger cathedral at St. Andrews, begun in 1162, shows how the Romanesque was at that date passing into First Pointed. In the conventual church of St. Thomas of Canterbury at Arbroath, founded in 1178, we see the Transition almost or altogether consummated. In the matchless crypt of the cathedral of Glasgow, founded in 1181 and consecrated in 1197, we have the First Pointed completely developed. In the cathedral church of Iona, on 
the other hand, Romanesque presents itself after the year 1200 ; but Irish hands were at work there, and the building is anomalous in other respects. One Romanesque feature, the semi-circular arch, lingered with us through every order to the last.

To the First Pointed or Early English style-including under that name as well the more advanced stages of Transition from the Romanesque as the earlier stages of Transition to Second Pointed-to the First Pointed style, extending over little more than one busy century from the accession of King William the Lion in 1165 to the death of Alexander III. in 1286-belong the chief portions of the cathedrals of St. Andrews, Glasgow, Galloway, Caithness, Elgin and Brechin, and of the conventual churches of Coldingham, Holyrood, Arbroath, Dryburgh, Paisley, Kiwinning, Inchcolm, Restennet, Dundrennan, New Ferne, Cambuskenneth, Inchmahome, Sweet Heart or New Abbey, and Pluscardine. They who are familiar with the architectural remains of Scotland, will at once perceive how many of our finest structures are included in this list.

If the Second Pointed style in England be held to extend from the accession of King Edward I. in 1272 to the accession of King Richard II. in 1377, we may affirm that up to its close-which nearly coincides with the accession of the house of Stewart to the Scottish throne-the ecclesiastical architecture of Scotland continued upon the whole to maintain its conformity with the contemporary ecclesiastical architecture of England. But the long and sanguinary wars of the Scotch Succession had now at length fixed the two countries in a position of antagonism-antagonism political, social, and even ecclesiastical. For, when the Papal schism broke out in 1378, England adhered to Urban VI. and Boniface IX., while Scotland followed Clement VII. and Benedict XIII. The point of difference was of consequence enough to affect the laity, and so to add the gall and bitterness of sectarian strife to the many causes which, on one hand, led Scotsmen to speak, even in the solemn language of the statute-book, of their " auld enemies of England"-and, on the other hand, led English fathers, in the northern counties, to declare, in their last wills, that their daughters should be disinherited if they married Scotchmen. Thus effectually estranged from her nearest and natural neighbour, Scotland 
was gradually drawn into close connection with France; and one fruit of this fellowship was that, from about the middle of the XVth to the beginning of the XVIIIth century, French influence prevailed more or less in every department of Scottish art.

The Second Pointed style, which, in England, came to a close about the year 1377 , may be regarded as extending itself, in Scotland, to the Reformation, with this distinction, 6 that, soon after the appearance of the Third Pointed or Perpendicular style on the southern side of Tweed, Scottish churches began to show the flamboyant window-tracery, the double doorways with flattened heads under one pointed arch, the large, richly-crocketted pinnacles, the polygonal apses or many-sided eastern terminations, and other characteristics of the contemporary architecture of France, of which you will hear more from my learned friend Mr. Burton, in the paper on the "Analogy of French and Scottish Architecture" with which he is to favour this section of the Archaeological Institute. Our Scotch Second Pointed style thus falls to be divided into two nearly equal portions, both comparatively barren (for sixty years of war with England had spent the strength and exhausted the resources of the country), the earlier portion belonging to what I have termed the AngloScottish period, the latter to what, I hope, we may be allowed to call simply the Scottish period. To the former are to be assigned the greater part of the beautiful cathedral church of Fortrose, and great part of the still more beautiful conventual church of Melrose - the latter dating from about the middle of the XIVth to about the middle of the XVth century, during most of which time Melrose stood on the English side of the Border, and its Cistercians gave their allegiance to the English Edwards, Richards, and Henrys. To this circumstance, perhaps, we may owe the tracery of Third Pointed character, which fills the great eastern window of Melrose. It is the only example of the Perpendicular style which is to be found in Scotland, with the exception of the four centred arches in the crypt of St. Triduan's chapel at Restalrig, built about 1486 by King James III., from a design, we may be allowed to conjecture, of some of his English favourites.

We can boast of no such temple as Melrose, in that later order of our Second Pointed style, which-extending from the accession of the first Stewart in 1371, to the accession 
of the sixth of our Jameses in 1567-fills the whole of the Third and last period of Scottish ecclesiastical architecture. To this age of decline, we are indebted for one cathedral church, that of St. Machar at Aberdeen, and for portions of five or six others, such as the choir of Lismore, the eightsided chapter-house of Elgin, the tower and western window of Brechin, the tower, nave, and chapter-house of Dunkeld, and the spire, nave, chapter-house, and transept-crypt of Glasgow. We are indebted to it also for the conventual churches of St. Monan's in Fife, the Black Friars at St. Andrews, the Greyfriars at Aberdeen and Stirling, for the gateway and refectory at Dunfermline, and the doorway and buttresses of the north isle of the nave of Holyrood. But its chief works were collegiate or parochial churches-such as those of Linlithgow, Corstorphine, Dalkeith, Seton, and Hïddington, in this neighbourhood; St. Mary's at Dundee, St. Saviour's at St. Andrews, St. John's at Perth, and King's College at Aberdeen. It is in this class of edifices-built chiefly during the second half of the $X V$ th, or the first half of the XVIth centuries-that French features are most conspicuous. Some of these Continental characteristics may still be discerned in St. Giles' Church in this city, in spite of the restoration to which it has been subjected. A still finer example of the style, was that Trinity College Church, which was so barbarously taken down a few years ago, and the rebuilding of which, to the deep disgrace of our Scottish capital, has not yet been begun. Nearly contemporary with Trinity College Church and St. Giles, is the collegiate chapel of Roslin, begun in 1446, and so wholly anomalous that it would be quite inexplicable were we not told that its founder brought the builders from abroad. It was these foreign masons, doubtless, who introduced into this little Scottish chapel the first features of Renaissance that are to be found perhaps within the British Islands.

If the Reformation was not so destructive of our ancient churches as has been commonly supposed, it was at least fatal for a time to the progress of ecclesiastical architecture. The sacred edifices which were built during the last hundred and fifty years of Scotland's existence as an independent realm, were as few in number as they were worthless in art. If we except one or two-such as Dairsie in Fife, Auchterhouse in Angus, and Ogston in Murray-which aspired to 
imitate English models of an earlier age, I believe that I name the best, when I point to the Tron Church in Edinburgh, as an example of that incongruous mixture of Gothic and Italian, Middle Age and Renaissance, which obtained in Scotland in the XVIIth century.

In beginning to speak of the Civil or Secular buildings of Scotland, I pass over-as works of engineering rather than 6 of architecture - our many hill-forts, whether ramparts of ¿ earth or stone, or walls more or less perfectly cemented by vitrification. I pass over, too, the numerous caves, cut like pigeon-holes in the face of precipitous cliffs, which served as ¿ places of refuge to our forefathers, so late even as the Eng$\infty$ lish invasions in the reign of King Henry VIII. Nor shall II do more than mention the low under-ground dens, called is weems, Earth-houses, or Picts Houses, where one long stone Doccessively overlapping another, served as a substitute for the arch, and so roofed in a hole in which the wild Scot, or barbarian Pict might find concealment and shelter for his in family, with their few scraps of dried deer's flesh, their If scanty heap of oats, and their little quern or hand-mill. In the Orkneys, and a few other northern counties, these subterranean or semi-subterranean chambers attain much larger dimensions, and show both greater resources, and more skill in construction. It is in the same district that we find the perplexing edifices called Burgs or Duns-circular erections of no great height, built of unhewn stones without cement, enclosing an open space in the centre, and having in the gradually diminishing thickness of the wall a succession of gradually diminishing chambers. It is very difficult to of determine either the use or the era of these singular structures. The subject has engaged the attention of an accomplished member of the Institute, Mr. A. H. Rhind, from whose pen, we may be assured, it will receive all the elucidation of which it is capable.

With abundance of Norman work still surviving in our churches, it is somewhat remarkable that we have now so little of Norman work to show in our castles. I cannot speak of any from my own observation, and do not remember to have read of any, except two Norman doorways at Closeburn, in Dumfriesshire, drawn and described by Cardonnel and Grose. Yet that many fortresses were built in Scotland during the 
prevalence of the Romanesque style, is not to be questioned. The castles raised by St. David, who reigned from 1124 to 1153, are expressly commemorated by his friend, servant, and biographer, St. Ailred; and the intimations of the Abbot of Rievaux are abundantly confirmed by chronicle, charter, and capitulary. But the son of St. Margaret planted his Norman keeps, for the most part, upon the Border ; and not only their ruins, but every vestige of the prosperous towns that grew up around their walls, have been swept from that unstable soil, by the frequent ebb and flow of the desolating tide of war. A few green mounds and shapeless heaps of stones are almost alI that now remain of the Roxburgh of the XIIth and XIIIth centuries ; its castle, mint, churches, chapels, hospitals, mills, and streets of trading booths. The other strongholds reared by St. David and his successors stood, with scarcely an exception, within burghs; and these, overspreading their ancient limits, have long obliterated the last traces of the feudal towers to which they owed their birth. At a still earlier period, the Wars of the Succession proved more fatal to Scottish castles than ever the Reformation was to Scottish churches. In the first six years of his reign, King Robert Bruce destroyed no fewer than a hundred and thirty-seven towers, castles, and fortalices, "Quia, sicut communiter adhuc dicitur," says the Cistercian annalist of Cupar, "nisi castra et turres exterminasset, regnum nequaquam in libertate gubernasset." We must keep in mind, too, that of the secular as well as of the ecclesiastical edifices of the north in the Middle Ages, many were of timber. Thus, it is recorded, that when the Wild Scots poured down from the hills, or swarmed across the firths, in 1228, to ravage the rich corn-lands of Murray, it was by wooden castles that they found the country defended. We have still in the Peel-bog of Lumphanan, the Bass of Inverury, the Doune of Invernochty, and elsewhere, the remains of the formidable earthworks, partly natural, partly artificial, on which such wooden towers were erected.

Setting aside mere fragments of ruin without any architectural expression-such as Dunbar, the seat of the great March Earls, or Lochmaben and Turnbery, Buitle, Dalswinton and Kynedar, Coull, Duffus and Boharm, ancient holds of the Bruces, Balliols, Cumyns, Durwards, and Murrays-Ican recall at this moment onlyone castle in Scotland, which can be proved 
from record to be of so old a date as the middle of the XIIIth century. "In the year 1267," says John of Fordun, " died Hugh Giffard of Yester, whose castle, at least its pit and donjon, were, according to old legends, built by demoniac art: for there is a wonderful cave beneath the ground, of admirable construction, stretching far into the earth, and commonly called Bohall." The Bohall, or Hall of Goblins, still remains in the Marquess of Tweeddale's park at 6 Yester, to attest the accuracy of description of the Father 응 our Scottish Chroniclers. The Lord of Yester chose for the site of his stronghold a steep peninsular mound, washed $\Xi$ by the Hopes burn on the one hand, and by a tributary of i that streamlet on the other. The situation had every ad$\infty$ vantage except one, water within the precincts of the castle; $\ddot{\sim}$ and it was to obtain this that the subterranean passage was \pm hewn, which excited the terrors of the East Lothian peasantry $\nabla$ in the XIIIth century. From a vaulted hall, which is itself below the natural surface of the soil, a vaulted staircase of six-and-thirty steps winds downwards into the bowels of the earth, until at the level of the neighbouring brooks a neverfailing supply of water is reached. The masonry of the work is not surpassed by any railway tunnel which I have had an opportunity of seeing. In other respects the edifice is too much ruined to be very instructive; but enough remains to show that the style was First Pointed, and that the decoration was of the same character as the ornamentation of the Scottish churches of the same time. For this conformity between our secular and ecclesiastical architecture we are prepared, both by the example of other countries, and by what is recorded of the only Medieval architect of Scotland whose name and works have descended to our day. The Scottish Breviary tells us how St. Gilbert of Murraywho built the cathedral of Dornoch in the XIIIth century, and filled its windows with glass made by himself on the coast of Sutherland-built also, and fortified many royal castles in the north.

The oldest fortresses now existing in Scotland, in anything like an entire shape, are what in England would be called Edwardian-a name which there are no reasons for rejecting in Scotland. It is in the Scotch wars of the first three Edwards, extending from 1296 to 1357, that these castles emerge into notice, if, indeed, as is much more probable, it 
was not that terrible struggle which called them into existence. The chief of them are Caerlaveroc on the Solway, Dirlton in East Lothain, which you will have an opportunity of visiting an hour or two hence, Bothwell on the Clyde, Kildrummy in Aberdeenshire, and Lochindorb in Murray. They have all the same general character - long curtain walls, flanked at the angles with lofty circular towers which are vaulted throughout--the entrance being by a drawbridge and gateway defended by a portcullis, and guarded on either side by a round tower. With the exception of Lochindorbwhich trusted not in vain for defence to the lake in which it stands-the walls are of great strength, and the area (generally of an irregular shape) which they enclose is of considerable size; that is, when measured by our Scotch standard, for I should think that one of the great Edwardian castles of the Welsh marches-Conway, Caernarvon, or Caerphilly-might hold two of our Scotch examples. In every instance which I know, the circular towers spring from their foundations in that bell-like shape with which we are all familiar, through representations of the Eddystone lighthouse. The absence of this peculiarity makes me hesitate to include Tantallon among the Edwardian castles, which it otherwise resembles, and to which it can be shown to approximate in point of date.

Of the next class of our northern castles-dating from the end of the XlVth to the middle of the XVIth centuriesthe primitive form is the square or oblong tower. In its simplest or humblest shape this was of 110 more than two storeys, both vaulted, the lower containing the kitchen, a well, and store-rooms, the upper occupied by the hall; the sleeping apartments, if there were any, being closets within the thickness of the wall. But it was seldom that the square tower had fewer than three storeys-there are instances of four and even five-the hall being still, for obvious considerations of safety, next the roof, while the lower, or underground chamber, accessible by a trap-door, which was the only opening, for there was neither chimney, airhole, nor window, served as the prison, or "pit," as it was called. The walls are for the most part very thick, measuring from ten to fifteen feet at the foundation, and containing within them newel staircases and one or two small chambers. The windows, except in the topmost storey, are 
mere slits, only a few inches wide at the exterior, but deeply splayed within. The entrance, as in the Irish Round Towers and in some of the Anglo-Norman keeps, was by a doorway (closed by an iron grate) in the second storey, to which there was access either by a ladder, or by a stone stair, built at some little distance from the tower, with which it communicated by a drawbridge. or more often, it would seem, by a moveable plank or two. Little more than a century has passed since at least one of these towers might have been seen in Scotland, inhabited, in almost every respect, as when it was first built, three hundred years before. James Ferguson, the self-taught astronomer, who lived for some months with Simon Lord Lovat in 1740, found his Lordship occupying the hall of Castle Downie, for all the purposes of drawing-room, parlour, dining-room, and bedchamber. "His own constant residence," we are told, "and the place where he received company, and even dined constantly with them, was just one room only, and that the very room in which he lodged. And his lady's sole apartment was also her own bed-chamber; and the only provision made for lodging either of the domestic servants or of the numerous herd of retainers was a quantity of straw which was spread over night on the floors of the four lower rooms of this sort of tower-like structure. Sometimes about 400 persons attending this petty court, were kennelled here."

Of these oblong towers-which were often allowed to remain in their original shape, as a refuge in emergency, long after their owners had begun to make their usual abode in lower and more commodious houses, "the laigh bigging," as our Scotch phrase ran-under the shadow of the old keep - of these rectangular towers, one of the earliest and best examples is that of Drum in Aberdeenshire. Merchiston in the suburb of this city, and Cawdor and Kilravock in Nairnshire, are excellent examples of the later style of the second half of the XVth century. Borthwick, about ten miles to the south of Edinburgh, is, without question, by far the noblest structure of this class which we possess. Built of ashlar within and without, it soars to the height of more than a hundred feet, and presents to the eye the appearance of two huge contiguous square towers. Differing in this regard from most others of the same style and age, its lofty, well-proportioned hall is in the second storey, an arrange- 
ment which may have been considered safe in this instance, where the tower was defended by an outer wall. At Craigmillar, within sight of Edinburgh, the rectangular tower has, as it were, an oblong block notched out of the south-west corner, where the doorway was so placed, at the top of a flight of steps, as to be protected by portholes commanding the approach at once in flank and front. Craigmillar boasts, perhaps, the finest specimen which we now possess of the antemurale, or barmkin, a defence which gradually became of more and more importance, as the use of fire-arms increased, until, in the beginning of the XVIth century, we find its presence expressly stipulated for among other appointments of the fortresses which crown vassals were taken bound to build. "A tower, with a barmkin, of stone and lime, a hall, a chamber, a kitchen, a pantry, a bakehouse, a brew-house, a barn, a byre, a cot, a pigeon-house, an orchard, and hedge-rows," - - so the enumeration runs in a charter of King James IV. in the year 1509. We are able to compare this catalogue of the requirements of a castle on the shores of Loch Ness with a contemporary list of the apartments of a mansion in the capital. The Edinburgh house of the Napiers of Merchiston, in 1495, contained "a hall, a chamber, a kitchen with a loft above, a pantry with a loft above, a chapel, three cellars, and a little house called the prison." At a somewhat later period, the barmkin seems to have fallen into disuse, its place being supplied by two circular towers, which being attached, one to each of the two opposite corners of the great rectangular tower, effectually flanked its walls on every side. Of this class of Scotch fortified houses, Drochil in Tweeddale, built by the Regent Morton in the minority of King James VI., is an instructive example.

In the middle of the XVth century, Scottish architecture, fostered by the love of art which the ill-starred King James III. transmitted to so many of his ill-starred descendants, began to recover from a long season of depression. But its progress was slow, and it is not until near the beginning of the XVIth century that we can be said to reach a new era. As one of its earliest fruits, I may mention the older portions of the Bog o' Gight, "our Palace of New Wark upon Spey," as it is proudly styled in the charters of its founder, George, second Earl of Huntly, who died in 1501. The building is 
now buried in the modern mass of Gordon Castle, so that we know it only in an engraving of the XVIIth century, which by a mistake in the lettering, calls it Inverary. The chivalrous King James IV. was, in the latter years of his reign, an energetic builder; but it is not easy always to distinguish between what he built and what was built by his son, King James V. It is important to know from our records that both princes employed Continental masons. In the reign of the former, an Italian was at work upon Holyrood-in the reign of the latter, Frenchmen were busy at Stirling, at Falkland, at Holyrood, and at Linlithgow. Of this last edifice, the finest altogether of our Scotch Palaces, the larger and better part belongs to the first half of the XVIth century. What it possesses "of foreign aspect is doubtless due, along with the foreign features of Stirling and Falkland, to their foreign builders. In Linlithgow, I may add, the ornamentation partook of the spirit of allegory which runs through the contemporary poetry of Dunbar, Gavin Douglas, and Sir David Lindsay. The now empty niches above the grand gateway in the eastern side of the quadrangle, were filled with statues of a pope, to represent the church, a knight, to indicate the gentry, and a labouring man, to symbolise the commons, each having a scroll above his head on which were inscribed a few words of legend, now irretrievably lost. All this I learn from records of the year 1535, which further show that this group, together with the group of the Salutation of the Virgin upon the other side of the quadrangle, and certain unicorns and a lion upon the outer gateway, were brilliantly painted. This external use of gaudy colour survived in Scotland to a comparatively late date. In the records of the year 1629 , for instance, I find a sum of 266l. charged for " painting his Maiesties haill rowmes in the Pallice of Linlithgow, both in sylringis, wallis, doris, windowis, bordaris above the hingingis ; and for furnisching all sortis of cullouris and gold belonging thairto: and lykwayes for painting and laying ouer with oyle cullour and for gelting with gold the haill foir face of the new wark-[that is the north side of the quadrangle, built by King James VT.] -with the timber windowis and window brodis, staine windowis and crownellis, with ane brod for the Kingis armes and houssing gilt and set of ; and lykwyse for gelting and laying ouer with oyle cullour the Four Orderis-[that is the vOL. XIII. 
Garter, the Thistle, St. Michael, and the Golden Fleece, all held by King James V.] -above the vtter yett, and furnisching all sortes of gold, oyle, and warkmanschip thairto, and for laying ouer the tuo vnicornes and gelting of thame." Metal work-cresting the tops of our buildings sometimes with a ballustrade, more often with figures of the cross, the thistle, the lion, and the like-was in general use in Scotch buildings-here again following the fashion of Franceduring the XVIth and XVIIth centuries; and we have proof that it was liberally painted and gilded. I have trespassed too far in this digression on the external use of colour to say anything of its internal application, except that this must have been very general. The vestiges of brilliant colouring are yet perceptible in the crypt of Glasgow ; and dim outlines of once resplendent forms are still to be discerned on the walls of the castle halls of Borthwick and Craigmillar.

If I give way to the temptation of saying something upon painted glass, it shall be but a sentence or two. In each of the five windows of the chapel in Linlithgow Palace was a figure or image of what the records of 1535 call "made work," that is, pieced work or mosaic. The price of this was $6 s .8 d$. a foot-the price of the white or common glass being $1 s, 1 d$. a foot-both sums, of course, being Scotch money. The five images cost altogether less than 10l., the plain glass in which they were set costing $15 l$. The painted glass of the five windows of the Lion Chamber of Linlithgow, executed in the same year, 1535 , cost $7 l$.; the common glass costing less than $4 l$.

To the same age with most part of the quadrangle of Linlithgow, the finest of our Palatial courts, belongs most part of the quadrangle of Crichton, the finest of our Castle courts. Here, again, we meet the marks of foreign taste. The peculiar ornament of the structure is in the sharp four-sided facets into which the stones are cut.

\footnotetext{
" Above its cornice, row on row Of fair hewn facets richly show Their pointed diamond forn."
}

And this kind of decorated masonry is found in France, according to $\mathrm{M}$. de Caumont, at an early period. Thirty or forty years later, perhaps, than the best portions of 
Crichton, the archiepiscopal castle of St. Andrews may be named as a favourable type of Scottish architecture in the middle of the XVIth century.

I now reach the last. the most prolific, and, as I think, the best age of Scotch secular architecture. King James V. was still busy with his buildings at Holyrood and Linlithgow, at Stirling and Falkland, when the fatal rout of Solway broke his heart in 1542. The tumults and wars of the Reformationextending through the distracted minority, and still more calamitous reign of his hapless daughter-were fatal to all the arts; and when at length they began to revive under the peaceful rule of King James VI., about 1570 , it was to show how vital a change had been wrought in architectural form and feeling during an 'interval of thirty years. Tendencies towards Renaissance may be found in all the buildings of King James V.; but when the unfinished works were resumed by his grandson, Renaissance, established in principle, was beginning to advance towards supremacy. Its progress, however, was so slow that it can scarcely be said, perhaps, to have completed its development until the reign of King Charles II. It is to the century preceding his death, from about 1570 to 1685 , that we owe what we may emphatically call the Scotch Castellated Style-that style which (still obviously deriving much from France) produced Strathbogie and Edzell, Fyvie and Castle Fraser, Crathes and Craigievar, Midmar and Craigston, Pinkie and Glammis. In almost all these, I think, as in most other instances, the architect was set to work on the square tower of the $X V$ th century as the nucleus of his composition ; and it is impossible not to admire the skill with which the old rectangular blocks are grouped into harmony with the new buildings to which they give dignity, vastness, and variety.

It is not unworthy of remark that in one or two cases where the history of the building has been ascertained, the owner would seem to have been his own architect. Pinkie and Fyvie assumed their present shape under the eye of Alexander Seton, first Earl of Dunfermline, who died in 1622, at the age of sixty-seren. His education, begun at Rome, was completed in France, where, doubtless, he acquired that "great skill in architecture" for which he is praised by his contemporaries. Glammis, again, became what it is, under the eye of Patrick, third Earl of Kinghorn and first Earl of 
Strathmore, who died in 1695 , at the age of fifty-two, leaving a memoir of what he did for his castle, in which he takes blame to himself for not consulting "any who in this age were known and repute to be the best judges and contrivers."

While one development of our Scottish architecture of the XVIIth century was into these princely chateaux, another development--congenial, at once, and contemporary-gave us such edifices as the Parliament House of Edinburgh, Moray House in the same city, Glasgow College, Winton House, Innes House, Argyll House at Stirling, one front of the courtyard at Falkland, and one of the courtyard at Caerlaverock - reaching its proudest triumph in Heriot's Hospital. Only a few years after the genius of Wallace, of Aytoun, and of Mylne had brought that noble pile to completion, Sir William Bruce of Kinross was commissioned to build a palace for our Scottish Kings. The result was Holyrood, almost the last edifice of mark built in Scotland before the Union. That event opened new fields for the display of the architectural taste and talents of our countrymen-but my task is done. It is beyond my province either to advert to what Gibbs, and Mylne, and the Adamses achieved during the last century on the other side of the Tweed, or to trace the fortunes on this, of that modern school of Scottish architecture which has never been adorned by more names of eminence, or by more works of merit, than at this hour. 